\title{
The Unexpected Consequences of War. Thucydides on the Relationship between War, Civil War and the Degradation of Language ${ }^{1}$
}

\section{Las inesperadas consecuencias de la guerra. Acerca de la relación entre guerra, guerra civil y degradación del lenguaje en Tucídides}

\author{
Dino Piovan ${ }^{2}$ \\ Università di Verona (Italia)
}

Recibido: 30-11-16

Aprobado: 15-01-17

\begin{abstract}
In this paper I intend to provide an analysis of Thucydides's account of war in the third section of his historical work (3.82-83). Despite some of his early commentators accused him of a certain obscurity, the notions of polemos and stasis he introduces in this text deserve to be discussed and can give a number of insights into the problem of civil war in Western history. My core argument is that there is a clear analogy between Thucydides's concept of stasis, from one hand, and Simone Weil's reflexions on totalitarianism and Klemperer's notebook on Nazi language, from the other hand. In this perspective, not only violence but also propaganda as a manipulation of language are important characteristics of stasis.
\end{abstract}

Key-words: Thucydides, Political Violence, Civil War, Totalitarianism, Fascism.

${ }^{1}$ Different drafts of this text were read in the conference series Classics Against 2015: War Theatres, the first one in Venice at St. Margherita Theater and the second one at the University of Trento; a shorter Italian version is now being printed (Piovan 2017). I thank those who organized both conferences and in particular Giorgio Ieranò for his wonderful welcome and for the stimulating debate in Trento. I also thank my friend Lucy Simonato for helping me to revise the English text and both the editors of this monograph section on Thucydides, Carlo Marcaccini and Antonis Tsakmakis.

2 (dinopiovan@gmail.com) Dino Piovan got the national scientific qualification as an university professor in Greek language and literature in 2013, after studying in Italy (University of Padova, Istituto Italiano di Studi Storici of Napoli, University of Pisa) and abroad (Wien, Münich in BayernLMU, London-UCL). At the moment he is teaching Greek at the University of Verona. Among other things, he published a commentary to Lysias' speech 25 (Padova, 2009) and the book Memoria e oblio della guerra civile (Pisa, 2011). 


\section{Resumen}

En este artículo pretendo aportar un análisis del relato de Tucídides de la guerra en la tercera sección de su obra histórica (3.82-83). A pesar de que algunos de sus primeros comentadores le acusaron de cierta oscuridad, las nociones de polemos y statis que él introduce en este texto merecen ser discutidas y pueden proporcionar ideas nuevas sobre el problema de la guerra civil en la historia de Occidente. Mi principal argumento es que existe una clara analogía entre el concepto de stasis de Tucídides, por un lado, y las reflexiones de Simone Weil sobre el totalitarismo y el cuaderno de Klemperer acerca del vocabulario Nazi, por otro. Dentro de esta perspectiva, no sólo la violencia, sino también la propaganda como manipulación del lenguaje son características importantes de stasis.

Palabras-clave: Tucídides, violencia política, guerra civil, totalitarismo, fascismo.

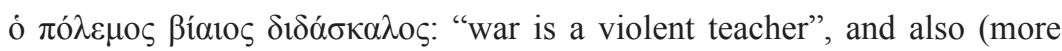
to it below) "war is a teacher of violence". So Thucydides writes at 3.82 in a sentence where the verb is elided, which gives an authoritative tone to his style. Chapters 82-83 of the third book have a particular importance in Thucydides's xyngraphe, the term that he himself uses to define his work and which is normally translated as "history". . As only rarely happens, Thucydides suspends his usually stark and sober narrative of events in order to draw an impressive outline of the consequences of stasis, "civil war", in many Greek cities. Before those chapters Thucydides describes the slaughter in Corcyra, caused by the violent conflict between democrats and oligarchs, triggered, or at least fostered, by the growing trend to bipolarization that invaded all the Greek world during the Peloponnesian war between Athens and Sparta (431-404 BC). The detailed account of those murders becomes a classical example of the general unrest in Greece, therefore it inevitably becomes a subject of the historian's meditation. It is a part of that ktema eis aiei, the "possession for ever", which Thucydides wants to deliver to his readers (cf. 1.22.4). His writing is here so hermetic and dense that even Greek native speakers in antiquity found it difficult to understand; even Dionysios of Halicarnassus, the famous rhetor and literary critic of the Augustan age, found it obscure ${ }^{4}$. This is probably the reason why this piece is hardly present in school books; one can find just some passages which are normally isolated from their

${ }^{3}$ To be true also chapter 3.84 deals with the negative consequences of stasis, but since antiquity most scholars have not considered it as original, even if someone tends to believe it as authentic, e.g. Polacco 2000-2001, whose general argument that Thucydides composed these chapters as a selfdefense from the charge of treason does not convince at all.

${ }^{4}$ See Dion. Hal., On Thucydides, 28; cf. to it the accurate analysis of Macleod 1979, 60-64, who argues that the rhetor of Augustean age did not understand Thucydides's critical passages. Dionysios's judgement is however shared by Polacco 2000-2001: 293. 
context and incomprehensible to young readers. This is in sharp contrast with the influence that the passage had on later authors, like Plato, but also non-Greek ones, like Sallustius ${ }^{5}$. Certainly this page demands a slow reading, or rather more than one reading only. In this paper only some of the most significant paragraphs of this famous section will be read in order to enlighten the relationship between polemos, 'war', and stasis in Thucydides's thought ${ }^{6}$.

(1) So the savage strife proceeded, and, because this was the first example of it, it seemed even worse than it was; later, practically the whole of the Greek world was in commotion, because in every state quarrels gave occasion to the democratic leaders to ask for aid from Athens, to the oligarchs to ask Sparta. In peace time, without the excuse and indeed without the readiness to summon them <they would settle their differences without fighting >; but in war and with an alliance at hand for either side, to injure their enemies and get more strength for themselves, request intervention were easily made by those ready for revolution. (2) Many were the calamities which befell the Greek states through this civil strife: they happened then and will happen again so long as human nature remains the same, with greater or less violence and varying only according to the changing conditions in each state. In peace and in prosperous times, both states and individuals are better disposed because they are not oppressed by inescapable wants; but war, destroying the ease of everyday life, is a violent taskmaster; and assimilates most men's tempers to the conditions around them (Thuc. 3.82.1-2).

Here each word is carefully thought and chosen, from the beginning: Ov́ $\tau \omega \varsigma$ $\dot{\omega} \mu \grave{\eta}<\dot{\eta}>\sigma \tau \alpha \dot{\sigma} \sigma \varsigma \pi \rho \circ \chi \chi \omega ́ \rho \eta \sigma \varepsilon$, "so the savage strife proceeded". The adjective

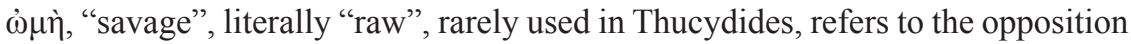
between raw and cooked that is a part of the food code of the Greeks and has had a highly symbolic value since the Cyclops passage in Odyssea IX, that is to say the opposition between barbarians and Greeks. This fact suggests that stasis is a decisive landmark to barbarity. The verb $\pi \rho \circ \chi^{\prime} \rho \eta \sigma \varepsilon$, "proceeded", usually means "to go ahead", "to move forward", and appears also at the beginning of Thucydides's work (1.16) in the so-called archaiologia, the "ancient history" of Greece, to denote the material progress of early Hellas, a progress that now has revealed itself as misleading. As to stasis, this is a noun which does not find an appropriate equivalent in any of the modern languages, so that it is

\footnotetext{
${ }^{5}$ Cf. P1., Resp. 560 d-e; Sall., Cat. 52.11; see Müri 1969: 73-77, for a wide overview of the reception of this Thucydidean passage.

${ }^{6}$ This quotation is from Gomme's English translation (Gomme 1956: 383-385). Incidentally, Gomme's commentary is still fundamental when reading and understanding Thucydides; a very useful updating is Hornblower 1991. Recent English translations are Hammond 2009 and Mynott 2013. Translations in other languages have also been consulted: the French one is Weil, de Romilly's 1967, the Italian ones are Cagnetta's, included in Canfora 1986, and Moggi's 1984. The bibliography on these Thucydidean chapters is vast so this paper has focussed on the most relevant essays; besides the already quoted commentaries of Gomme and Hornblower, Edmunds 1975; Macleod 1979; Connor 1984: 95-105; Loraux 1986; Orwin 1994: 175-182; Price 2001: 6-78; Hawthorn 2014: 96-101.
} 
often improperly translated as "sedition" or "revolt", or even "revolution"7. It may seem paradox that stasis is derived from a verb that indicates a state and not a movement, namely histemi, "to make to stand, to set up" and "to stand"; consequently stasis is, literally, the stance that splits the citizens in two opposite parties to be involved in a conflict, an armed clash, or even a civil strife as in this case $^{8}$.

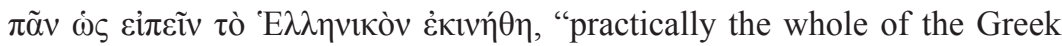
world was in commotion": here the verb is ekinethe from kineo, "to move", that unavoidably recalls kinesis, 'motion, movement', a key term of Thucydides's proem (cf. 1.1.2). Maybe it is exactly this passage from the third book that makes a proper understanding of the phrase in the proem possible: kinesis, the 'motion' which his work is dedicated to, does not concern only the military dimension of the city-states in war, that is battles and deads, victories and defeats, but it is a phenomenon that permeates society as the whole and the individual man in his soul; it is a civil, moral, psychological and even linguistic turmoil, as it will be soon seen.

There are some repeated words in the original Greek text as the syntagma $\varepsilon v$

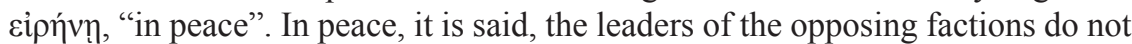
dare to call for help from the foreign powers, Athens and Sparta, because they had no ground nor they were ready, that is to say they did not think at all about that. Here Thucydides refers to what was happening inside the Greek city-states; it does not mean that all went well in peace time or there was no conflict at all inside the poleis, but that it was just the war that created the conditions which brought internal divisions to deteriorate, to the point that tensions became overwhelming and violence erupted.

Thucydides's focus extends beyond the space of to hellenikon, the world inhabited by Greek people, so to include the human condition in its entirety: $\check{\varepsilon} \omega \varsigma$

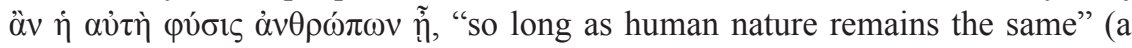
sentence which will be discussed further late on). In peace and prosperity times the poleis and the people are better, the Greek expression sounds so: they have better gnomai. The word gnome can be translated in different ways, as "intelligence", or in a less abstract way as "judgement", "opinion", even "intention", but not any judgement or any kind of intention, that is the important point. Gnome is what has been examined in a thoughtful way, the fruit of reasoning, the result of a rational

\footnotetext{
${ }^{7}$ Cf. Bertelli 1989: 53-55, who rightly invites to distinguish ancient stasis from modern revolution that aims at an epochal change in society and a new start in history, both purposes which are unknown to ancient stasis. It is therefore misleading to translate stasis with revolution without any clarification as does e.g. Zagorin 2005: 89-95.

${ }^{8}$ Cf. Radici Colace, Sergi 2000 for a deep semantic analysis of the word stasis. There is an ample bibliography about stasis in ancient Greece; some essential references are here quoted: Lintott 1982 , Gehrke 1985 and Rhodes 2015 from a historical perspective, Bertelli 1989 and Bertelli 1996 from a philosophical one, Manicas 1982 and Berent 1998 from an anthropological one. Eventually Loraux 2006 is a book which collects many of her contributions, in which philological, historical, literary and philosophical analyses cross.
}

Araucaria. Revista Iberoamericana de Filosofia, Política y Humanidades, año 19, nº 37. Primer semestre de 2017. Pp. 181-197. ISSN 1575-6823 e-ISSN 2340-2199 doi: 10.12795/araucaria.2017.i37.09 
proceeding. In peace times what prevails are the intentions arisen out of a rational process, because according to Thucydides men do not fall in anankas akousias, "involuntary necessities". Ananke is what cannot be governed by human will, the inescapable; ananke and relative words recur in the first book (cf. e.g. 1.23.6) when the historian maintains that the Peloponnesian war is not so much the result of the different reasons for conflict, but is rather the unavoidable outcome of a more and more stretched competition for leadership between the two biggest state powers, Athens and Sparta.

The point is that war cancels the euporia, the "wellness" of daily life, and conforms the orgai of most people to temporary situations. Orgai are emotions, feelings, uncontrolled drives; they are in antithesis with peace-time gnomai. Therefore polemos becomes biaios didaskalos, that is a "violent teacher" but also, I would say, "a teacher of violence", or both at the same time: war is violent teacher who teaches to use violence ${ }^{9}$. Thucydides does not affirm that war unveils which the real human nature is, as it is sometimes interpreted ${ }^{10}$. It is true that the historian says that atrocities caused by stasis "happened then and will happen again so long as human nature remains the same". However the meaning of this sentence is not so much that human nature is rigid, fixed, immutable, but that it is used to react to some situations in a similar way but with different expressions according to the metabolai ton xyntychion, the "changing conditions". Therefore war is not a teacher who unveils the real core of human nature, but who rather forces it into a definite direction, a state of necessity which is opposite to the rational will. It is well known that stasis is frequently execrated in Greek literature both before Thucydides and in his age, too ${ }^{11}$; examples abound so that it may be sufficient to refer to the significant association between stasis and phonos found in both Theognis and Herodotus ${ }^{12}$. However stasis usually appears in antithesis to

\footnotetext{
${ }^{9}$ Many scholars translate 'violent master', e. g. Haase 1894: 134: “violentus est magister”; Weil, de Romilly 1967, ad locum: "maître aux façons violentes"; Moggi 1984, ad loc.: "maestra dal carattere violento"; Hornblower 1991: 482: "violent schoolmaster"; Rhodes 1994, ad loc.: "violent teacher"; Mynott 2013, ad loc.: "a violent master". Other people however prefer "master of violence", so e.g.

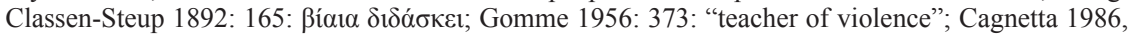
ad loc.: "maestra di violenza". It seems something in-between the translation of Hammond 2009, ad loc.: "war [...] runs a violent school". Even modern lexica disagree: according to Liddel-Scott-Jones, s.v. Bíatos, it means "teaches by violence"; for Montanari s.v. "maestra violenta". Mazzocchini 2002 compares this Thucydidean expression with other passages in Greek literature and in particular one in Teognides's corpus (1.649-652) in which $\pi \varepsilon v i ́ \alpha$, "poverty", is said that it "teaches vile things by violence", so he argues we have to exclude the interpretation "master of violence" for "violent master". The analogies he suggests are really interesting but why should scholars rule out the possibility that Thucydides uses poetic tradition in an original way, giving a new meaning to an expression which is anyway only partly present in this tradition? If one looks at the general context of this passage, in which war is seen as a factor that provokes violence, it is easier to feel more in agreement with Connor 1984: 102, n. 57, who sees a deliberate Thucydidean ambiguity.

10 So for example Wassermann 1954, and MacLeod 1979.

${ }^{11}$ Cf. the passages quoted by Loraux 1986: 97-98. Also Il. 9.63-64 could perhaps be added: the word stasis is not present, but the situation can be assimilated: "A clanless, lawless, hearthless man is he that loveth dread strife among his own folk" (the translation is by A.T. Murray).

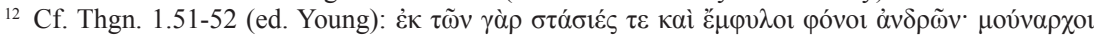


polemos, the war against the external enemy of the polis ${ }^{13}$, the only conflict which can give the glory of immortality to the soldiers fallen in battle.

This is the famous theme of dulce et decorum est pro patria mori, which recurs also within Thucydides's work in the famous speech delivered by Pericles in the second book ${ }^{14}$ for the Athenian dead in the first war year. However, if the historian seems indebted to the literary tradition by painting the effect of $\operatorname{stasis}^{15}$, the connection between stasis and polemos appears as an entirely Thucydidean peculiarity. It is now opportune to make some broader points about this historian.

The modern age has often celebrated Thucydides as the historian for excellence, the most objective, able to reveal the true nature of international relations based on force and not on right. Consequently the dialogue between Athenians and Melians in the fifth book (5.85-115) is one of the most quoted and admired Thucydidean pages; the arguments Melians advance there, based on justice, respect for tradition, and gods' protection, are mercilessly torn to pieces by the relentless logic of power claimed by Athenian imperialism. Thucydides is still today considered the ancient master of political realism; so it was for Thomas Hobbes and later for the German historical school between XIX and early XX century, from Leopold von Ranke to Eduard Meyer. In international relations Thucydides is regarded as the founder of realism. Sometimes he has been raised to a forerunner of Machiavelli by going to the real truth of the matter rather than the imagination of it, to use a Machiavellian expression $^{16}$, someone adverse to any insane utopia ${ }^{17}$. Thucydides has been admired as a model historian, looking at reality, the ugly reality, as it is truly, without any veil linked to moral or religious concerns. In conclusion Thucydides is viewed as an amoral thinker, if not immoral, someone far from traditional morality, so he is evoked as such by Nietzsche in his work Twilight of the Idols:

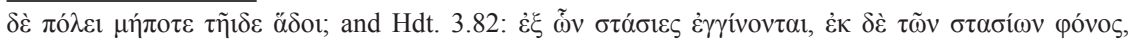

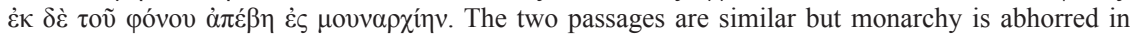
Theognis whereas in Herodotus the speaker Darius, the future Persian king, considers it the best possible government.

${ }^{13}$ A famous case in which stasis and polemos are opposite each other is in Aesch., Eum. 858-866; cf. also Pl., Resp. 470b-d; Leg. 628b-629d.

${ }^{14} \mathrm{Cf}$. in particular 2.42.4, where it is said that the fallen in war "in the briefest moment, at the turning point of their fortune, they took their leave not of fear but of glory" (Hammond's translation). This theme is also present elsewhere, for example in Lysias's Epitaphios: cf. Lys. 2.25; about this topic Meier 1990.

15 So in particular Edmunds 1975, who, however, tends to bring back Thucydides to literary tradition too much, especially to Hesiodus, whereas Loraux 1986 evidences how complex the relationship between the historian and the tradition on stasis is: if he has truly a debt towards that, he also shows a meaningful variance.

${ }^{16}$ Machiavelli's famous expression so sounds in the original: "mi è parso più conveniente andare drieto alla verità effettuale della cosa, che alla immaginazione di essa" (Il principe, cap. 15.3).

17 Reception studies on Thucydides have been prospering in the last years; there are now three volumes reserved to this subject: Fromentin, Gotteland, Payen 2010; Harloe, Morley 2012; Lee, Morley 2015. In particular about Thucydides and Hobbes cf. Iori 2015; about Thucydides and modern realism cf. Marcaccini 2015 and Johnson 2015; about Thucydides and the German XIX-century historians cf. Piovan 1995 and Meister 2015; on Thucydides and the international relations see Gustafson 2000; Lebow 2012; Keene 2015; on Thucydides and Nieztsche cf. Zumbrunnen 2015: 301-308, where there is a quite original interpretation of Nieztsche as a constructivist reader of Thucydides.

Araucaria. Revista Iberoamericana de Filosofia, Política y Humanidades, año 19, nº 37. Primer semestre de 2017. Pp. 181-197. ISSN 1575-6823 e-ISSN 2340-2199 doi: 10.12795/araucaria.2017.i37.09 
Thucydides as the great summation, the final appearance of that strong, strict, hard factuality that was a matter of instinct for the older Hellenes. Courage in the face of reality is, in the final analysis, the point of difference between natures such as Thucydides and Plato. Plato is a coward in the face of realityconsequently he flees into the ideal; Thucydides has control over himselfconsequently he also has control over things ... (Nietzsche 1997: 88).

However this rereading would like to suggest doubt that things are really so, or not completely so at least. In this passage, one of the very few in which the historian directly speaks with his own voice without the unfathomable filter of an impersonal narration, almost every line seeps a wounded morality, which is shocked by the perversions of which it is a powerless witness ${ }^{18}$. The perversion of language is one of the most powerful. We have to turn now to 3.82.3-4:

The customary meanings of words were changed as men claimed the right to use them as they would to suit their actions: an unreasoning daring was called courage and loyalty to party, a prudent delay specious cowardice; moderation and self-control came to be reckoned but the cloak of timidity, to have understanding of the whole to be everywhere unwilling to act. A capricious cunning was added to the brave man's portion; to deliberate for long so as to avoid mistakes was supposed a well-thought excuse for avoiding action (Gomme's translation).

Thucydides is not saying that the meaning of words simply changed, as it is often interpreted; this would be anyway a normal phenomenon in every language for many words. What Thucydides seems to say is that the words kept having their normal positive or negative meaning but what they described began to change ${ }^{19}$. The successive examples do not let doubts to begin with the first one: tolma alogistos, "unreasoning daring", was considered andreia filetairos, "courage and loyalty to party". Tolma alogistos means hazard before logos (here "reason") has pondered all factors, that is to say the courage lacking in the awareness that situations are complex. It is this behaviour that is praised in stasis times and considered as andreia filetairos, literally "courage in favour of one's own group", that is of one's own

${ }_{18}$ According to Edmunds 1975, Thucydides would be imbued with an ethic traditionalism which goes back to Hesiod; the analogies with the poetic tradition are further analyzed by Mazzocchetti 2002. Maybe the bitter morality that pervades this Thucydidean passage and many others has less to do with the literary tradition and more to do with the political, military, intellectual and civil setback of Thucydides own generation which had lived the endless series of Peloponnesian war disasters, from plague to Sicilian failure to the final capitulation. However the expressive forms can be related to a literary tradition Thucydides does not ignore. Against the thesis that Thucydides "betrays a regret for the certainties of an old hierarchical order" see Hawthorn 2014: 100.

19 About the meaning of this sentence see Hogan 1980 and Wilson 1982, followed now by most scholars, among whom also Nussbaum 2004: 751, n. 24. However Orwin 1994: 177 n. 11 is against their interpretation. 
faction or, to use a modern term, party ${ }^{20}$. On the contrary the use of logos, the wisdom that refuses rushed action for thoughtful decisions, is accused of lacking courage, of concealing itself behind nice pretexts; the intelligence that tries to understand the complexity of the whole is qualified as ineptitude. A little further it is explained that (3.82.8): "The cause of it all was love of power (arché) to gratify greed (pleonexia) and personal ambition (filotimia); from that came the eagerness to quarrel which appeared once strife had begun" (Gomme's translation).

To sum up, stasis consists in the triumph of a rabid activism driven by greed and ambition which, to use a Nietzschean expression, could be called Wille zur Macht, a "will to power" that is unrestrained by traditional moral values and actually perceives them as a useless obstacle. Family bonds, for example, become "more foreign than party" (82.6), which predisposes one even more to unreasoning daring; and the bond within a friends' group gets stronger by trespassing both human and divine laws. Of course, the officially declared reason of this struggle is not power; faction leaders publicly use "fine-sounding names" (82.8) as "equality for all free citizens" and "prudent government by the best"; they pretend they care a lot about ta koina, "the public interest" (one would say "res publica" in Latin), understood as both "the common good" and "the state", but to be true it is just the prize of a competition in which what mostly matters is prevailing over one's own opponents at any price, without being restrained by what can be considered right or useful for the community. And ta mesa ton politon, "those citizens who were neutral", who did not want to take side for one of the two parties, those who refused extremism, diephtheironto, "were destroyed".

If reading classics today makes sense when it stimulates thought and is not an occasion for a ritual homage that is often a prelude to a sepulchral, intellectual dismissal, it is hard to resist the temptation to collocate side by side Thucydides's sharp and severe remarks with other, not less sharp and not less severe, remarks written in a much more recent age, in the middle of the Second World War, by Simone Weil, the French thinker who reflected so originally and intensively on the Greek heritage. During that war Weil dedicated a short and pressing essay to contemporary political parties's ideology ${ }^{21}$ in which she described its three basic features in this way:

1. A political party is a machine to generate collective passions.

2. A political party is an organisation designed to exert collective pressure upon the minds of all its individual members.

3 . The first objective and also the ultimate goal of any political party is its own growth, without limit (Weil 2013: 24).

\footnotetext{
${ }^{20}$ As it has been argued elsewhere, it is not possible to speak of 'parties' in classical Athens using the contemporary meaning; see Piovan 2015.

21 This essay was originally written in London in 1943 some time before Weil's premature death and firstly published in French seven years later.
}

Araucaria. Revista Iberoamericana de Filosofia, Política y Humanidades, año 19, nº 37. Primer semestre de 2017. Pp. 181-197. ISSN 1575-6823 e-ISSN 2340-2199 doi: 10.12795/araucaria.2017.i37.09 
"A machine to generate collective passions": does not the expression "collective passions" sound maybe as an equivalent of the Greek orgai that annihilate the gnomai? "Collective pressure upon the minds of all its individual members": here it is easy to think of the drive to conformism that orgai inevitably create when they are collective but also of the threat to those who do not follow the tolma alogistos and are branded as coward, weak, not virile, and also of the tendency to make party ties prevail over all other ones (family, polis, religion). Weil's last and basic feature of a political party: "The first objective and also the ultimate goal of any political party is its own growth, without limit", refers in other words to a "will to power" which, as suggested above, is a possible modern translation of the Greek pleonexia. Pleonexia becomes eventually the struggle for power without any other aim, in which ta koina, the res publica, are reduced to a prize for winners, without any limit formed by a sense of fairness and common good.

There is also another essay by Weil which can be compared to the page by Thucydides on stasis. In 1937 Simone Weil was meditating on the causes of contemporary war after having personally experimented the Spanish Civil War as a volunteer. Her basic idea is that conflicts are unleashed by fake, empty but murderous words as the following passage makes clear:

For the clear-sighted, there is no more distressing symptom of this truth than the unreal character of most of the conflicts that are taking place today. They have even less reality than the war between the Greeks and Trojans. At the heart of the Trojan War there was at least a woman and, what is more, a woman of perfect beauty. For our contemporaries the role of Helen is played by words with capital letters. If we grasp one of these words, all swollen with blood and tears, and squeeze it, we find it is empty. Words with content and meaning are not murderous... However when empty words are given capital letters, then, on the slightest pretext, men will begin shedding blood for them and piling up ruin in their name, without effectively grasping anything to which they refer, since what they refer to can never have any reality, for the simple reason that they mean nothing. In these conditions, the only definition of success is to crush a rival group of men who have a hostile word on their banners; for it is a characteristic of these empty words that each of them has its complementary antagonist. It is true, of course, that not all of these words are intrinsically meaningless; some of them do have meaning if one takes the trouble to define them properly. But when a word is properly defined it loses its capital letter and can no longer serve either as a banner or as a hostile slogan; it becomes simply a sign, helping us to grasp some concrete reality or concrete objective, or method of activity. To clarify thought, to discredit the intrinsically meaningless words, and to define the use of others by precise analysis - to do this, strange though it may appear, might be a way of saving human lives (Weil 2005a: 241-242).

There is here a kind of assonance with Thucydides 3.82.8: "The leading men of either side in the cities armed themselves with fine-sounding names, equality for all free citizens or prudent government by the best, but all alike made a prize 
of the public interest which they pretended to be serving" (Gomme's translation). This assonance is probably a sheer coincidence; Weil knew Thucydides's work but what most attracted her attention was the dialogue between Athenians and Melians and especially the sentence at 5.105.2 which she quoted many times in her Notebooks ${ }^{22}$ :

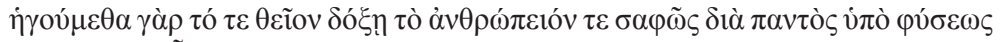

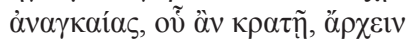

We believe it of the gods, and we know it for sure of men, that under some permanent compulsion of nature wherever they can rule, they will (Hammond's translation).

It is not a surprise that Weil meditated so much on this sentence by Thucydides. In the age of such totalitarian regimes as Fascism, Nazism and Communism she was pondering upon this apparently new phenomenon of modern history which she believed it had very old roots in antiquity, in the cult of power and strength. The first expression of this centrality of force was found by her already in the first literary work of European tradition, in Homer's Iliad, to which she dedicates the excellent essay The Iliad or the Poem of Force ${ }^{23}$. Force is the core of the poem, she maintains:

The true hero, the true subject, the centre of the Iliad is force. Force employed by man, force that enslaves man, force before which man's flesh shrinks away. In this work, at all times, the human spirit is shown as modified by its relations with force, as swept away, blinded, by the very force it imagined it could handle, as deformed by the weight of the force it submits to. For those dreamers who considered that force, thanks to progress, would soon be a thing of the past, the Iliad could appear as an historical document; for others, whose powers of recognition are more acute and who perceive force, today as yesterday, at the very centre of human history, the Iliad is the purest and the loveliest of mirrors (Weil 2005b: 183).

However force has no allure in Homer, no charme; at the end it will reveal itself just an illusion and a fate of pain expects both the defeated and the winners:

violence obliterates anybody who feels its touch. It comes to seem just as external to its employer as to its victim. And from this springs the idea of a destiny before which executioner and victim stand equally innocent, before which conquered and conqueror are brothers in the same distress. The conquered brings misfortune to the conqueror, and vice versa (Weil 2005b: 199).

${ }^{22}$ The sentence at Thuc. 5.105.2 is quoted at least eight times in Weil's Notebooks, as the excellent indices of the complete Italian translation prove (see Weil 1982-1993). The only English edition I have found in Italian libraries is Weil's 1970, which is not complete because it was published before the entire French edition was available. Anyway the Thucydidean passage quoted above is here so translated: "He [God] refrained from «commanding wherever he had the power»" (Weil 1970: 81).

${ }^{23}$ Originally published as L'Iliade ou le poème de la force in 1940-41; the following English translation is by M. McCarthy. 
Just as for the Iliad, one could maintain that Thucydides's work appears

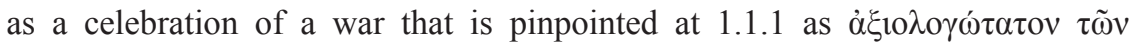
$\pi \rho \gamma_{\varepsilon} \varepsilon v \eta \mu \varepsilon ́ v \omega v$, "more momentous than any previous conflict" (Hammond's translation), but at the end what seems most important in his narration are the pains war caused to people while "no space is given to heroic behaviour in battle, differently than in other historians" 24 . What most captured Thucydides's mind seems to be constituted by the pathemata, "sufferings", enumerated in 1.23.1-3, which is much more than a rhetorical device, as Ugo Fantasia observes in his penetrating interpretation.

There is also another European intellectual contemporary of Simone Weil who could be recalled for his meditation of the manipulation of words and its catastrophic effects on civil life: Victor Klemperer, a Romance philologist, who was persecuted by the Nazis because of his Jewish origin, but was not deported to a concentration camp because his wife was Aryan. So he stayed in Germany as an inner exile. After the war he published a notebook in which he documented the linguistic changes during the Third Reich, hence the title acronym: LTI, Lingua Tertii Imperii. The here quoted passage is quite remarkable:

Language does not simply write and think for me, it also increasingly dictates my feelings and governs my entire spiritual being the more unquestioningly and unconsciously I abandon myself to it. And what happens if the cultivated language is made up of poisonous elements or has been made the bearer of poisons? Words can be like tiny doses of arsenic: they are swallowed unnoticed, appear to have no effect, and then after a little time the toxic reaction sets in after all ${ }^{25}$.

The point is not that Klemperer says the same things as Thucydides, but both writers grasped an essential element: words are not just ornament, they are a basis of civil life and their manipulation is a part of the degradation and disintegration of society ${ }^{26}$. Of course, there are some obviously important differences between Thucydides's age, on the one hand, and Weil's and Klemperer's one, on the other; what the latter were living was the age of extremes, to recall Eric Hobsbawm ${ }^{27}$, that is the time of totalitarianism, a very specific characteristic of the XX century. Without forcing too much this analogy between the stasis Thucydides describes and the political mood of the Thirties in the past century there is maybe another possible element in common between the two historical situations that is worth highlighting. The totalitarian, European parties of the time between the two wars were, at least partly, the result of the First World War and its consequences. Postwar Europe experienced a new kind of inner violence which some contemporary

\footnotetext{
${ }^{24}$ Fantasia 2012: 43 .

25 Klemperer 2006: 14.

${ }^{26}$ The idea of compare Thucydides to Klemperer is owed to Bonazzi 2016: 44. Quite different is the case of George Orwell's Animal Farm, where an ironic intent prevails (see Hawthorn 2014: 101 n. 21).

27 The obvious reference is Hobsbawm 1995.
} 
historians explained with the thesis of the brutalization of society as a direct consequence of the war. If the brutalization thesis is now under discussion ${ }^{28}$, that seems still to be convincing in the case of Italy. Fascism would not have been possible without that war, as the great historian Federico Chabod acknowledged a long time ago $^{29}$. It was the war that created the conditions for the fascist movement to arise and establish itself, even if there were also other factors that contributed to its success; these other factors, however, would not have been enough. What is here particularly interesting is that the First World War was really a biaios didaskalos, "a violent master" and "a master of violence". Emilio Gentile, maybe the major living historian on Italian Fascism, expresses clearly this connection, even if he does not present it as the only cause of the collapse of the liberal state:

Fascist paramilitary violence was for the most part the consequence of combat experience in the Great War, but it was also the cause of the collapse of any hope of creating a safer world for democracy... Italy was the first country to succumb to paramilitary violence and to experience the collapse of its democratic regime. Moreover, this occurred following a period in which violence had taken a rapid upturn: for example, deaths by homicide numbered 938 in 1918 and rose to 1,633 in 1919 , to 2,661 in 1920 and to 2,750 in $1921 \ldots$ Paramilitary violence was introduced into Italy by new organizations made up of ex-combatants, such as the Arditi (shock troops), the Fasci di combattimento founded by Mussolini in March 1919 and the armed movement led by the poet Gabriele D'Annunzio in the occupation of Fiume in September 1919... Paramilitary violence was adopted by fascist squads, assembled by young veterans of the Great war, in a systematic campaign of destruction against the political organizations and trade unions of the working class ${ }^{30}$.

Still following Gentile's reconstruction, "the habit to brutality, familiarity with danger and death, disregard for human life, practised during the war by millions of people, loosened the inhibitory ties in society" (Gentile 2013: 130). Therefore it is arguable that the First World War taught violence and a kind of tolma alogistos to people that took part in it. As it has been already said above, the first team of Fascist movement was constituted by veterans, former fighters who came back home transformed by that experience. It is also not exaggerated, I believe, to see Fascism as the exit of a stasis in Italian society, the result of a civil war in which a party took power using both violence and propaganda. The unscrupulous manipulation of language is in fact an important characteristic of Fascism that cannot be underestimated. The infamous fascist motto "Believing, obeying, fighting" could be recommended as an equivalent of Thucydides's tolma alogistos; this fascist slogan connotes positively a behaviour of blind audacity,

\footnotetext{
${ }^{28}$ See Gerwarth, Horne 2013a: 3-11. For the brutalization thesis see the bibliography quoted in the same volume, p. 3. n. 6 .

29 See Chabod 1981.

${ }^{30}$ Gentile 2013: 128, 130, 135 (in this quotation also the English edition of Gentile's essay is used, which is however shorter than the Italian one).
} 
not driven by intelligence but committed to one's own party. There are actually some contemporary historians who openly speak of the first Italian post-world period as a civil war, even if this thesis is not accepted by other ${ }^{31}$.

Maybe these analogies will seem excessive but as March Bloch once said, it is impossible to understand the past without bending over the present. Thucydides fosters the awareness that stasis with all its terrible perversions is not just the casual effect of a war, even if unforseen and undesired by those who support the war. If Thucydides is a realist thinker, it seems not really true that morality is just an illusion to him. If anything, it is worth following Steven Forde's opinion: “Thucydides's accounts of the destruction of civilized decency in these circumstances show that he finds the truth of the realist view undeniable. But it is not for him the whole truth" ${ }^{\prime 2}$. If any, it is a lesson still much to be pondered upon ${ }^{33}$.

${ }^{31}$ It is especially Fabio Fabbri who maintains that the first post-war in Italy was a civil war; see Fabbri 2009: IX-XXVII. Gentile 2013: 129 agrees with it whereas Detti 2011 does not and admits only a metaphoric value of 'civil war' in the Italian case. About the connection between political violence and the origins of Fascism see also the very recent synthesis of Albanese 2016: 47-65. There is also someone who interprets the entire European history between 1914 and 1945 as a civil war with an extended use: Traverso 2007.

32 Forde 2000: 157.

${ }^{33}$ Hawthorn 2014 alerts to the sometimes too easy generalizations by Thucydides. Rhodes 2011 invites to read Thucydides as an author to think about. 


\section{Bibliography}

Albanese 2016: G. Albanese, Dittature mediterrane: sovversioni fasciste e colpi di stato in Italia, Spagna e Portogallo (Roma-Bari, 2016).

Berent 1998: M. Berent, Stasis, or the Greek Invention of Politics, "History of Political Thought" 19.3 (1998), pp. 331-362.

Bertelli 1989: L. Bertelli, Stasis: la rivoluzione dei Greci, “Teoria politica", 5.2-3 (1989), pp. 53-96.

Bertelli 1996: L. Bertelli, La stasis dans la démocratie [in M.-L. Desclos, éd.: Réflexions contemporaines sur l'antiquité classique, Grenoble, 1996], pp. 11-38.

Bonazzi 2016: M. Bonazzi, Con gli occhi dei Greci (Roma, 2016).

Canfora 1986: L. Canfora, ed., Tucidide, La Guerra del Peloponneso (Tomo 1, libri 1-3) (Bari, 1986).

Chabod 1981: F. Chabod, L'Italia contemporanea, 1918-1948 (26. ed., Torino, 1981).

Classen-Steup 1892: J. Classen, J. Steup, Thukidides, III (Berlin, 1892).

Connor 1984: W.R. Connor, Thucydides (Princeton, 1984).

Detti 2011: T. Detti, Il primo dopoguerra in Italia: una guerra civile?, "Passato e presente", 84 (2011), pp. 176-181.

Edmunds 1975: L. Edmunds, Thucydides'Ethics As Reflected In the Description of Stasis (3.82-83), "HSPh", 79 (1975), pp. 73-92.

Fabbri 2009: F. Fabbri, Le origini della guerra civile: l'Italia dalla Grande Guerra al fascismo, (1918-1921) (Torino, 2009).

Fantasia 2012: U. Fantasia, La guerra del Peloponneso (Roma, 2012).

Forde 2000: S. Forde, Power and Morality in Thucydides [in Gustafson 2000], pp. 151-173.

Fromentin, Gotteland, Payen 2010: V. Fromentin, S. Gotteland, P. Payen, eds.: Ombres de Thucydide (Bordeaux, 2010).

Gentile 2013: E. Gentile, La violenza paramilitare fascista e le origini del totalitarismo in Italia [in Gerwarth, Horne 2013], pp. 127-154.

Gerwarth, Horne 2013: R. Gerwarth, J. Horne, eds.: Guerra in pace: violenza paramilitare in Europa dopo la Grande Guerra (Milano-Torino, 2013; original edition Oxford, 2012).

Gerwarth, Horne 2013a: R. Gerwarth, J. Horne, Il paramilitarismo in Europa dopo la Grande Guerra. Un'introduzione [in Gerwarth, Horne 2013], pp. 1-26.

Gomme 1956: A.W. Gomme, A Historical Commentary On Thucydides, II: Books 2-3 (Oxford, 1956).

Gustafson 2000: L.S. Gustafson, ed.: Thucydides's Theory of International Relations: A Lasting Possession (Baton Rouge, 2000). 
Harloe, Morley 2012: K. Harloe, N. Morley, eds.: Thucydides and the Modern World (Cambridge, 2012).

Haase 1894: F. Haase, Thucydidis Historia belli Peloponnesiaci (cum nova translatione latina, Parisii, 1894).

Hawthorn 2014: G. Hawthorn, Thucydides on Politics: Back to the Present (Cambridge, 2014).

Hobsbawm 1995: E. Hobsbawm, The Age of Extremes: The Short Twentieth Century, 1914-1991 (London, 1995).

Hogan 1980: J.T. Hogan, The axiosis of Words at Thucydides 3.82.4, "GRBS", 21 (1980), pp. 139-149.

Hornblower 1991: S. Hornblower, A Commentary on Thucydides, I: Books I-III (Oxford, 1991).

Iori 2015: L. Iori, Thucydides Anglicus, Gli Eight Bookes di Thomas Hobbes e la ricezione inglese delle Storie di Tucidide (1450-1642) (Roma, 2015).

Johnson 2015: L. M. Johnson, Thucydides the Realist? [in Lee, Morley 2015], pp. 391-405.

Keene 2015: E. Keene, The Reception of Thucydides in the History of International Relations [in Lee, Morley 2015], pp. 355-372.

Klemperer 2006: V. Klemperer, The Language of the Third Reich, LTI- Lingua Tertii Imperii, A Philologist's Notebook (translated by M. Brady, LondonNew York, 2006; original edition Halle, 1957).

Lebow 2012: R.N. Lebow, International Relations and Thucydides [in Harloe, Morley 2012], pp. 197-211.

Lee, Morley 2015: C. Lee, N. Morley, eds.: A Handbook to the Reception of Thucydides (Chichester, 2015).

Lintott 1982: A. Lintott, Violence, Civil Strife and Revolution in the Classical City, 750-330 BC (London-Camberra, 1982).

Loraux 1986: N. Loraux, Thucydide et la sedition dans les mots, “QS” 23 (1986), pp. 95-134.

Loraux 2006: N. Loraux, La città divisa: l'oblio nella memoria di Atene (Vicenza, 2006; original edition Paris, 1997).

Macleod 1979: C.W. Macleod, Thucydides on Faction (3.82-83), "PCPhS" 25 (1979), pp. 52-68.

Manicas 1982: P. Manicas, War, Stasis and Greek Political Thought, "Comparative Studies in Society and History", 24.4 (1982), pp. 673-688.

Marcaccini 2015: C. Marcaccini, Politica e passioni in Tucidide: il dibatitto su Mitilene [in A. Campi, S. De Luca, eds.: Il realismo politico, Soveria Mannelli, 2015], pp. 103-117.

Mazzocchini 2002: P. Mazzocchini, Polemos biaios didaskalos: modelli etici e tradizione letteraria in Thuc. III 82-83, “Eikasmós” 13 (2002), pp. 105-119.

Meccariallo 2016: A. Meccariello, Per una critica della ragione totalitaria: l'analisi di Simone Weil [in L.A. Manfreda, F. Negri, A. Meccariello, eds.: Esistenza e storia in Simone Weil, Trieste, 2016], pp. 183-203. 
Meier 1990: C. Meier, Il ruolo della guerra nell'Atene classica [in M. Sordi, ed.: "Dulce et decorum est pro patria mori": la morte in combattimento nell'antichità, Milano, 1990], pp. 69-94.

Meister 2015: K. Meister, Thucydides in Nineteenth-Century Germany [in Lee, Morley 2015], pp. 197-217.

Moggi 1984: M. Moggi, ed.: Tucidide, La guerra del Peloponneso (Milano, 1984).

Müri 1969: W. Müri, Politische Metonomasie (zu Thukydides 3, 82, 4-5), "MH” 26 (1969), pp. 65-79.

Mynott 2013: J. Mynott, Thucydides, The War of the Peloponnesians and the Athenians (Cambridge, 2013).

Nietzsche 1997: F. Nietzsche, Twilight of the Idols, Or How to Philosophize with the Hammer (translated by R. Polt, introduction by T. Strong, IndianapolisCambridge, 1997; original edition Berlin, 1969).

Nussbaum 2004: M.C. Nussbaum, La fragilità del bene. Fortuna ed etica nella tragedia e nella filosofia greca (Bologna, 2004²; original edition Cambridge, $2001^{2}$ ).

Orwin 1994: C. Orwin, The Humanity of Thucydides (Princeton, NJ, 1994).

Piovan 1995: D. Piovan, Tucidide in Germania: tra storicismo e filologia, "Patavium", 5 (1995), pp. 35-68.

Piovan 2015: D. Piovan, Partiti e democrazia in Atene classica, "Filosofia politica" 29.1 (2015), pp. 39-52.

Piovan 2017: Tucidide, la stasis e la corruzione del linguaggio [in A. Bonandini, E. Fabbro \& F. Pontani, eds.: Teatri di guerra. Da Omero agli ultimi giorni dell'umanità, Milano-Udine, 2017], pp. 121-143.

Polacco 2000-2001: L. Polacco, Tucidide difende se stesso dall'accusa di tradimento (Thuc. III 82-84), “Atti dell'Istituto Veneto di Scienze, Lettere ed Arti”, 159 (2000-2001), pp. 293-311.

Price 2001: J. Price, Thucydides and Internal War (Cambridge, UK, 2001).

Radici Colace, Sergi: P. Radici Colace, E. Sergi, Stasis nel lessico politico greco, “ASNP”, s. IV, 5.1 (2000), pp. 223-236.

Rhodes 1994: P.J. Rhodes, Thucydides, History III (Oxford, 1994).

Rhodes, 2011: P.J. Rhodes, Biaios Didaskalos? Thucydides and his Lesson for his Readers [in G. Rechenauer, V. Pothou, eds: Thucydides - a violent teacher?, Goettingen, 2011], pp. 17-28.

Rhodes 2016: P.J. Rhodes, Instability in the Greek Cities [in V. Goušchin, P.J. Rhodes, eds.: Deformations and Crises of Ancient Civil Communities, Stuttgart, 2015], pp. 27-46.

Traverso 2007: E. Traverso, A ferro e a fuoco: la guerra civile europea, 19141945 (Bologna, 2007).

Wassermann 1954: F. Wassermann, Thucydides and the Disintegration of the Polis, "TAPhA", 85 (1954), pp. 46-54. 
Weil, de Romilly 1967: R. Weil, J. de Romilly, eds.: Thucydides, La guerre du Péloponnèse (livre III) (Paris, 1967).

Weil 1970: S. Weil, First and Last Notebooks (engl. transl. New York-Toronto, 1970).

Weil 1982-1993: S. Weil, Quaderni, I-IV (Milano, 1982-1993; original edition Paris, 1970-1974).

Weil 2005: S. Weil, An Anthology (London, 2005).

Weil 2005a: S. Weil, The Power of Words [in Weil 2005], pp. 238-258.

Weil 2005b: S. Weil, The Iliad or the Poem of Force [in Weil 2005], pp. 182-215.

Weil 2013: S. Weil, On the Abolition of All Political Parties (engl. transl. New

York, 2013; original edition Note sur la suppression générale des partis politiques, in Eadem, Écrits de Londres et dernières lettres, Paris, 1957).

Wilson 1982: J. Wilson, 'The Customary Meanings of Words Were Changed- or Were They?'A note on Thucydides, 3.82.4, "CQ", 32.1 (1982), pp. 18-20.

Zagorin 2005: P. Zagorin, Thucydides, An Introduction For the Common Reader (Princeton-Oxford, 2005).

Zumbrunnen 2015: J. Zumbrunnen, Realism, Constructivism, and Democracy in the History [in Lee, Morley 2015], pp. 296-312. 
